\title{
Article
}

\section{SMEs and Certified Management Standards: The Effect of Motives and Timing on Implementation and Commitment}

Iatridis, Konstantinos, Kuznetsov, Andrei and Whyman, Philip B Available at http://clok.uclan.ac.uk/13362/

Iatridis, Konstantinos, Kuznetsov, Andrei ORCID: 0000-0003-4539-0711 and Whyman, Philip B ORCID: 0000-0002-3926-1019 (2016) SMEs and Certified Management Standards: The Effect of Motives and Timing on Implementation and Commitment. Business Ethics Quarterly, 26 (1). pp. 67-94. ISSN 1052$150 X$

It is advisable to refer to the publisher's version if you intend to cite from the work. http://dx.doi.org/10.1017/beq.2016.9

For more information about UCLan's research in this area go to http://www.uclan.ac.uk/researchgroups/ and search for <name of research Group>.

For information about Research generally at UCLan please go to http://www.uclan.ac.uk/research/

All outputs in CLoK are protected by Intellectual Property Rights law, including Copyright law. Copyright, IPR and Moral Rights for the works on this site are retained by the individual authors and/or other copyright owners. Terms and conditions for use of this material are defined in the policies page.

\section{CLoK}

Central Lancashire online Knowledge www.clok.uclan.ac.uk

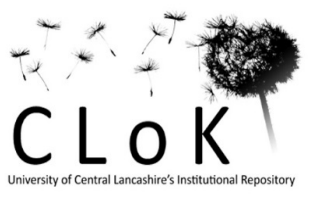


SMEs and Certified Management Standards: The Effect of Motives and

\title{
Timing on Implementation and Commitment
}

\author{
Konstantinos Iatridis ${ }^{\alpha}$, \\ School of Management, \\ University of Bath, \\ Bath, BA2 7AY, UK
}

Email: k.iatridis@bath.ac.uk

Tel: +44(0)1225385311

\author{
Andrei Kuznetsov \\ School of Business, \\ University of Central Lancashire \\ PR1 2HE, Preston, UK \\ Email: $\underline{\text { AKuznetsov@uclan.ac.uk }}$ \\ Tel.: +44 (0)1772 894695
}

\section{Philip B Whyman}

School of Business,

University of Central Lancashire

PR1 2HE, Preston, UK

Email: PBWhyman@uclan.ac.uk

Tel: +44 (0)1772 894693

$\boldsymbol{\alpha}$ : corresponding author 
Abstract: Existing research on certifiable management standards (CMS) and corporate social responsibility (CSR) tends to focus on large companies and is characterised by disagreement about the role of these standards as drivers of CSR. We contribute to the literature by shifting the analytical focus to the behaviour of small and medium-sized enterprises (SMEs) that subscribe to multiple CSR related standards. We argue that, in respect of motive and commitment, SMEs are not as different from large companies as the literature suggests, as they are guided by similar institutional and economic motives. Results, based on ISO 9001, ISO 14001 and OHSAS 18001 certified SMEs in Greece, demonstrate that later adopters are more susceptible to coercive and mimetic motives and are less likely to commit fully to the CMS requirements, while earlier adopters react to normative motives and considerations of internal efficiency gains and tend to carry out CMS requirements with greater diligence.

Keywords: Certified management standards, SMEs, corporate social responsibility, motives, implementation, Greece 


\section{Introduction}

The proposition that business should operate in the interests of society, over and above its own maximisation of commercial objectives, has become increasingly prominent in recent decades. This shift in the perception of business conduct has led to calls in the literature for greater attention to the relationship between institutions and corporate responsibility (Arya \& Zhang, 2009; Wijen, 2014). This paper focuses on the interconnections between certified management standards (CMS) and socially responsible business conduct. CMS are institutions that play a significant role internalising consideration of corporate social responsibility (CSR) within aspects of business strategy (Cannon, 2012). Many CMS address issues related to the implementation of CSR, albeit to a different degree and often indirectly. Despite their significance and a general agreement that CMS are important as governance mechanisms for firms' conduct, there are conflicting views on their effectiveness and role in promoting a socially responsible behaviour on the part of businesses. Whilst many theorists claim they are essential (Hodgson \& Cicmil, 2007; Schaefer, 2007), others are sceptical about their usefulness (Aravind \& Christmann, 2011; Behnam \& MacLean, 2011).

Three factors contribute to this absence of consensus in the literature. The first is that, thus far, extensive scholarly interest in firms' motives to subscribe to CMS and in the degree of commitment that they show towards CMS requirements (Agan et al., 2013; Allur et al., 2014; Heras-Saizarbitoria, 2011; Potoski \& Prakash, 2013; Singh et al., 2015; Zailani et al., 2012) has not produced a majority view on which factors influence conformity to CMS and whether CMS improve CSR performance (Aravind \& Christmann, 2011; Heras-Saizarbitoria \& Boiral, 2013a). There is, as a result, an acknowledged research gap regarding the true potential of CMS to promote CSR (Rasche, 2010). 
The second factor concerns the somewhat static nature of CMS analysis, given that it often assumes an intact regulatory environment, within which the values of social communities prescribe appropriate business behaviour (Palazzo \& Scherer, 2006). In fact, although standards might promote stability and 'sameness' among organisations, they represent, in reality, a dynamic phenomenon and thus research design needs to take this into account (Brunsson et al., 2012).

The third factor is that scholarship relating to the impact of CMS upon promoting responsible business conduct draws its material predominantly from the examination of large firms, and particularly multinational corporations (Russo \& Perrini, 2010). The relative paucity of research evaluating the impact of CMS upon small and medium enterprises (SMEs) is a shortfall that requires urgent attention (Vázquez-Carrasco \& López-Pérez, 2013; von Weltzien Høivik \& Shankar, 2011) given their economic significance within developed nations.

In light of these limitations, this paper contributes to the literature both empirically and theoretically. Empirically, first, by introducing new firm level data; second, by investigating firms that have adopted a bundle of standards rather than a single standard; third, by presenting a dynamic rather than a static view of standards through comparison of earlier and later adopters of CMS; fourth, by focusing on SMEs instead of large companies; and, fifth, by investigating a less explored institutional context, namely Greece. Theoretically, the paper contributes to both the CSR and CMS streams of literature by examining the extent to which the conclusions drawn from the existing literature, based disproportionately upon the behaviour of large firms, are relevant in the case of SMEs subscribing to multiple CMS. The paper's results challenge studies that highlight the difference in attitudes to, and practices of, CSR between SMEs and large companies (Ciliberti et al., 2008; Enderle, 2004; Jamali et al., 2009; 
Perrini, 2006; Preuss \& Perschke, 2010; Russo \& Perrini, 2010; Sweeney, 2007). The paper suggests that, depending on the context, SMEs tend to react in a similar fashion to larger enterprises given that they are influenced by an essentially similar set of institutional and economic motives.

Utilising regression analysis of primary (survey) data, this paper examines the motivations of SME respondents related to the adoption of CMS and their commitment to the implementation of the full range of standard provisions. In particular, the paper seeks to determine whether dissimilarities persist between earlier and later adopters of CMS. If the existence of dissimilarities in motives and implementation is confirmed, this may be used as ground for making conclusions about the role of these standards as an institution that promotes CSR performance in an SME context and as an instrument of self-regulation in general. In fact, using the example of the impact of CMS on CSR, the paper demonstrates that process based selfregulation, not supported by strict sanctions, loses its edge as the numbers of adopters increase. Our results suggest that SMEs responding to coercive and mimetic pressures for the adoption of CMS are associated with a lower probability of substantial implementation of all CMS requirements. By contrast, SMEs that react to normative motives and pursue internal efficiency gains, following the implementation of CMS, are more likely to integrate CSR consistently within their business operations. The former type of behaviour is found to be characteristic of later adopters while the latter is more typical of earlier adopters.

The paper's conceptual framework draws on institutional and business strategy theories. Institutional theory has established that there is a meaningful difference between earlier and later adopters of a business practice, as these two groups face dissimilar pressures from the institutional environment and may adopt the same practice for different reasons. Earlier 
adopters are assumed to be driven mostly by the technical advantages that such practice offers and for this reason they are expected to apply it substantially in the sense that they will fully commit to its requirements. In turn, later adopters are more inclined to adopt a practice for legitimacy purposes and as a result they are expected to apply this practice symbolically, meaning that they will not genuinely attempt to conform to the requirements of the practice (Tolbert \& Zucker, 1983). As for business strategy and competitive strategy theory in particular, this paper relies on the literature that demonstrates that the adoption of CMS might be driven by internal efficiency factors such as cost savings and greater productivity (Bansal \& Bogner, 2002; Lannelongue et al., 2013). By drawing on these two literatures, we seek to consider in our research both external and internal factors that may affect the effectiveness of CMS in triggering socially responsible business conduct in SMEs.

The empirical data has been collected through a primary survey of ISO 9001, ISO 14001 and OHSAS 18001 certified SMEs operating in Greece, thereby recognising the large-scale expansion of management standards across European Union member states, whilst expanding the literature beyond its current concentration upon the US, China and a narrow range of larger European economies. The rest of the paper is organized as follows. Section two, after discussing the salient features of CMS, introduces the research hypotheses and, in doing so, provides commentary on previous research. Section three describes the empirical methodology, and section four presents the results. Section five discusses the paper's findings while the final section provides the main conclusions, implications and highlights directions for future research. 


\section{Theoretical approach}

\subsection{Certified management standards}

Certified Management Standards (CMS) are formal technical documents, issued mainly under the auspices of international organizations, such as the International Organisation for Standardization (ISO), that establish criteria, methods, processes and practices intended to help firms improve their internal organisation and operational efficiency. CMS serve as frameworks that assist firms in developing their own management practices. They are the product of a wide multi-stage consultation process in which various groups of stakeholders are involved, including business experts, consumer associations, Non-Governmental Organisations (NGOs), academics, governmental authorities and, in some cases, testing laboratories. The fact that CMS are developed by expert groups grants them a certain status in the eyes of both practitioners and the public, as an instrument of legitimisation (Terlaak, 2007a). Because of public perceptions of certified management standards as tokens of respectability and legitimacy, they have acquired significant symbolic value, i.e., value related to the image they project rather than to the advantages of proper application that businesses are keen to exploit. Along with practical benefits, the symbolic value of CMS has facilitated their proliferation and wide acceptance as a form of self-regulation.

CMS share several common characteristics. First, they are process rather than performance standards. They require firms to develop and apply a particular management system. The implementation of the system is subject to regular audits during which the management system and its components are thoroughly examined and compared with the standard's requirements by external auditors. Second, most CMS are applicable to all organizations irrespective of size or industry. Third, in contrast to statutory regulations, these standards promote a voluntary 
approach to CSR implementation, since their adoption is not mandatory and there is no central authority to impose them, monitor their execution or sanction violations.

\subsection{Certifiable management standards and corporate social responsibility}

CMS have been developed in response to a growing demand for the establishment of managerial norms that would have a wider public acceptance and recognition, in an attempt to provide common criteria for the evaluation of corporate activities and the facilitation of managerial practices (Claessens \& Yurtoglu, 2012). Most standards reflect the seven fundamental CSR principles set by the ISO: accountability, transparency, ethical behaviour, respect of stakeholders' interests, respect for the rule of law, respect for international norms of behaviour and respect for human rights (ISO, 2010). As a result, the implementation of these standards directs businesses towards operating in a socially responsible way (Jiang \& Bansal, 2003). Accordingly, CMS are often described in the literature as an effective means of applying CSR practices and are promoted as organizational models that help firms to boost their legitimacy and credibility with stakeholders (Mueller et al., 2009). Indeed, in many corporations they have become a significant element of the CSR effort (Schaefer, 2007).

CMS have, additionally, been widely identified in the literature as a key foundation of a global governance mechanism for corporate social behaviour and self-regulation (Delmas \& MontesSancho, 2011; Jamali, 2010). They have enabled the formation and reproduction of shared meanings and understandings, thereby creating a kind of a "common language" of CSR that can be understood by different categories of stakeholders (Brunsson et al., 2005). CMS have been strongly favoured by the European Commission because they have been instrumental in developing a common perception of acceptable corporate behaviour, and thus have facilitated 
the formulation and application of relevant common policies in all European Union member states (European Commission, 2003).

Amongst those CMS that assist companies in applying CSR practices three have proved particularly popular, namely ISO 9001, ISO 14001 and OHSAS 18001 . They account for the vast majority of all certifications worldwide (BSI, 2013; ISO, 2014). Of these, ISO 9001 is the most adopted CMS in the world, being implemented by over 1.1 million companies and organizations in over 170 countries (ISO, 2014). This standard assists organisations in implementing a quality management system and its role as a CSR related tool, as is the case with many CMS, may be not explicit at first glance. In fact, it deals, inter alia, with such important aspects of CSR as consumer/employee protection and has been extensively used as a means of introducing CSR into many countries (Tencati et al., 2008). Such major organizations as the Organisation for Economic Co-operation and Development (OECD), the European Commission and the United States Council for International Business have included it in their lists of the most well-known CSR initiatives (European Commission, 2003; OECD, 2009; USCIB, 2013). In addition, ISO 14001 and OHSAS 18001 encourage CSR behaviour by supporting process requirements related to environmental protection and health and safety in the workplace (Aravind \& Christmann, 2011).

It is these three popular standards that this paper uses in its analysis. They are considered as a group on the basis that CMS may complement one another and are, therefore, neither exclusive of, nor competing with, each other (Delmas \& Montes-Sancho, 2011). As Rasche (2009) points out, although CMS might deal with different subject matters, they should be used, at least for analysis purposes, as a joint category as they all aim at holding firms accountable for their operations and decisions. 
ISO 9001, ISO 14001 and OHSAS 18001 mandate that certified firms develop policies on quality, environment, together with health and safety. They must state explicitly their objectives and responsibilities towards their stakeholders and, in addition, explain how their operations ensure stakeholder satisfaction (Biazzo \& Bernardi, 2003). These standards insist upon openness, from participating organisations, about those decisions and activities that affect society, together with their communication in a clear, accurate, timely, honest and complete manner (ISO, 2009). To achieve this, the standards stipulate certain procedures, such as internal and external audits and management reviews, which assist companies in avoiding questionable practices and promote transparent and credible operations (Arya \& Salk, 2006; Castka \& Balzarova, 2007). While complementing one another, each of these standards has a specific CSR related focus. For example, ISO 9001 ensures that companies do not practice price gouging, make misleading advertising claims or sell ineffective, unreliable and unsafe products. Similarly, ISO 14001 contributes towards protecting the rights of local communities through the application of pollution control measures. Finally, OHSAS 18001 ensures safer and healthier workplaces, alongside avoidance of negligent practices that may threaten employee integrity. Furthermore, the three standards indirectly deal with respect for human rights by advancing fundamental principles and rights at work, including forbidding the employment of children, use of forced/ compulsory labour, promoting education and training in the workplace and preventing discrimination at work (Göbbels \& Jonker, 2003).

Individually and collectively, these three standards provide firms with valuable guidance on how to engage in CSR related practices. They set clear requirements related to various aspects of CSR and define processes for firms to follow to satisfy these requirements. Overall, they assist businesses in creating a meaningful CSR agenda by supplying the needed directions for monitoring their activities and constantly improving their CSR performance. Externally, these 
standards set communication procedures between the company and its stakeholders, allowing the latter insights into how the firm meets their expectations and demands.

\subsection{Conceptual framework and hypotheses building}

Establishing organisational motives for implementing CMS helps to unveil the true strength of commitment of businesses to this CSR tool (Zailani et al., 2012). The institutional approach has been widely used as a conceptual framework for understanding the motives and implementation of CSR related practices (Aravind \& Christmann, 2011; Campbell, 2007; Delmas \& Montes-Sancho, 2011; Marano \& Kostova, 2015). Institutions embody norms and values prevalent in societies and define the current perception of what is legitimate (Scott, 2001). Institutional embeddedness theory investigates the interconnections between an organisation and its institutional environment. It argues that organizations that adhere to institutional prescriptions of appropriate conduct, obtain rewards that include greater legitimacy, status and enhanced access to resources (Baum \& Oliver, 1992).

To reap these benefits, organisations have to make their adherence explicit. Subscribing to CMS provides such an opportunity due to their dual nature. Whilst being technical documents designed to help firms to adopt best practices in management (Heras-Saizarbitoria \& Boiral, 2013a), they are also created or endorsed by authoritative international establishments and are intended to reflect the interests of broad categories of stakeholders. Therefore, CMS act as an embodiment of socially acceptable managerial norms directing businesses towards operating in a socially responsible way (Jiang \& Bansal, 2003). Significantly, this duality of purpose creates conditions for a duality of application as these standards may be adopted predominantly for signalling purposes (Terlaak, 2007b) when firms seek to exploit their symbolic value to 
send a compliance message to stakeholders or, instead, substantially for gaining chiefly the operational benefits associated with the application of the standards.

The two facets of CMS imply that the choice between symbolic and substantial implementation depends on the interplay of forces representing institutional isomorphism and the competitive marketplace. In respect to the former, DiMaggio and Powell (1983), in their widely quoted article, propose that there are three categories of institutional pressure, namely coercive, normative and mimetic, that direct organizations towards isomorphism or homogeneity. A firm may be coerced to adopt CMS by pressure from stakeholders, such as requirements imposed upon the supply chain by larger companies (Heras-Saizarbitoria \& Boiral, 2013a). Normative forces refer to societal expectations towards organizations to behave in accordance with societal norms, beliefs and values (Schaefer, 2007). In this context, SMEs might adopt CMS, for example, as a statement of integrating corporate responsibility into their business strategy (Cannon, 2012). Finally, mimetic pressures refer to symbols, cultural rules and frameworks that are taken-for-granted, i.e. their connection to social norms, values and beliefs is not questioned (Hoffman, 1999). Indeed, the wide acceptance of CMS by the EU, many national governments and NGOs may increasingly turn these standards into tokens of respectability, thereby leaving SMEs little choice but to get on the bandwagon.

Isomorphic institutional pressures do not, however, necessarily result in homogeneous implementation of CMS. Critics of the institutional isomorphism approach draw attention to internal drivers as factors mitigating external institutional influences. They maintain that firms do not simply passively react to such pressures but are instead dynamic and active, and their response to external forces depends on the firms' own resources and capacities (Allur et al., 2014; Boiral \& Henri, 2012; Castka \& Prajogo, 2013; Guoyou et al., 2012; Nair \& Prajogo, 
2009). Firms may be attracted to CMS because of the internal benefits they produce in the form of a better use of available capacities, reduced cost, enhanced efficiency and productivity, and product quality improvement (Boiral \& Amara, 2009; Neumayer \& Perkins, 2005). The implication is that firms are likely to fully conform to the CMS requirements only when there are performance improvements to be gained from these standards (Salomone, 2008).

Summarising the view of scholars, it is apparent that Jamali (2010) made a valid comment when she concluded that, from a managerial perspective, the motives and implementation of CMS reflect "trade-offs between legitimacy and efficiency, between dependence and independence, between discretion and constraint" (Jamali, 2010: 635). It may appear that a logical conclusion from this observation is that every case of the adoption of a voluntary standard is individual and specific to circumstances. In reality the literature argues that the adoption motivation, and the degree of the implementation of standards, can be expected to reliably differentiate between earlier and later adopters (Delmas \& Montes-Sancho, 2007). Earlier adopters have been found to be driven mostly by the competitive advantages that a new practice has to offer; e.g., the degree to which the change improves the firm's financial and operational performance. For that reason, earlier adopters are inclined, it is argued, to commit fully to the practice's requirements and in this sense would implement it substantially (Montiel $\&$ Husted, 2009). By contrast, later adopters are more disposed to mimic the environment with the objective of embracing a practice as a means to maintain or increase legitimacy and, as a result, they are likely to apply this practice symbolically, implying that they would not genuinely attempt to integrate the requirements of the standard in own operation (Naveh et al., 2004). 
The paper, therefore, tests whether this dichotomy between earlier and later adopters holds for small and medium-sized firms with respect to CSR related CMS. It also investigates whether these two groups of adopters differ in how they react to institutional pressures and economic considerations (the motives of increasing internal efficiency) when choosing to subscribe to a bundle of standards. To achieve these objectives the paper examines five hypotheses that describe the motivation and behaviour of earlier and later adopters.

\subsubsection{Coercive motives}

Existing studies suggest that the most influential external factors that force companies to adopt CMS are linked to customer and peer pressures and market requirements (Corbett, 2006; Potoski \& Prakash, 2004). It has been found that firm size matters as far as time of adoption and motives for adoption of CMS are concerned (Rivera et al., 2006). Large firms are more visible to external stakeholders and thus are more compelled to adopt CMS in early phases (Guller et al., 2002; Mori \& Welch, 2008). In addition, larger organisations are more likely to be earlier adopters because they have the resources required to invest in identifying and implementing opportunities stemming from the adoption of management standards (Mori \& Welch, 2008). Large firms not only implement CMS first, but also may play an active role in their diffusion through requiring their suppliers to adopt CMS (Montiel \& Husted, 2009). With time, the pressures exerted by this group of earlier adopters transform CMS into a quasi-formal market requirement. Because SMEs have limited resources, they tend to adopt new managerial practices, such as CMS, either when they are certain that these are beneficial to them or when they are forced to do so by changes in the market environment. In the case of CMS, the literature singles out the pressure from larger companies as a major incentive for adoption (Baumann-Pauly et al., 2013). When SMEs and large firms are linked within a supply chain, the pressure to subscribe to CMS may either derive from mandated requirements, imposed 
upon suppliers, or through more subtle means of information dissemination and the sharing of best practice (Lewis \& Cassells, 2010). Either way, SMEs end up adopting management standards or engaging other CSR related tools in order to maintain their competitive position within the chain (Cote et al., 2006). Given the essentially reactive nature of this behaviour on the part of SMEs, it is plausible that this kind of pressure will have a more significant influence upon later rather than earlier adopters. This leads to the following hypothesis:

Hypothesis 1: The later the time of CMS adoption by SMEs, the greater the influence of adopters' perceptions of coercive motives on CMS implementation.

\subsubsection{Normative motives}

Normative motives are fundamentally of moral origin and embolden ethical and responsible behaviours regardless of the outcomes (Hemingway \& Maclagan, 2004). They make another group of influential drivers behind the adoption of CMS by SMEs. The European Network for SME Research (ENSR) Enterprise Survey 2001, for instance, indicates that a substantial section of European SMEs adopt CMS because "it is the right thing to do", with the importance of ethical reasons increasing as the size of the firm gets smaller (European Communities, 2002). In SMEs, normative motives are particularly strong in the case of CSR related activities (Mandl \& Dorr, 2007). In the literature, the focus of SMEs on moral values and norms is attributed to two circumstances. The first is the fundamental role of the entrepreneur's beliefs and value system in shaping SMEs strategy (Perrini \& Minoja, 2008). The second is the fact that, because SMEs are largely local in their area of operation, their survival depends to a great extent on good relationships with their stakeholders, and in particular the local community. Accordingly, the maintenance of a good reputation becomes central to small businesses' success, encouraging SMEs to abide by ethical norms and to get involved in CSR as important prerequisites for gaining trust and respectability (Ciliberti et al., 2008; Murillo \& Lozano, 2006; 
Russo \& Perrini, 2010). This may have important consequences in terms of the timing of the adoption of CMS, as some SMEs may seek competitive advantages by being proactive in respect of finding opportunities to raise their social profile (Aguilera et al., 2007). Consequently, it may be assumed that these are likely to choose to be early adopters of CMS. Thus, we hypothesise that:

Hypothesis 2: The earlier the time of CMS adoption by SMEs, the greater the influence of adopters' perceptions of normative motives on CMS implementation.

\subsubsection{Mimetic motives}

Mimetic isomorphism occurs when certain organisational practices become "normatively sanctioned" (DiMaggio et al., 1983), i.e., when they are adopted by firms-trendsetters, get wide societal backing and gain the reputation of "best practice". Displaying isomorphism with other firms allows SMEs to obtain legitimacy benefits and lower the costs of acquiring vital resources (Hillebrand et al., 2011). CMS are ideal candidates for mimetic isomorphism as the institutional environment in the Western economies has consistently promoted CMS adoption (Delmas \& Montes-Sancho, 2011). However, it necessarily takes time for a practice to achieve a status that makes managers recognise that imitation is worthwhile or even inevitable. Hence:

Hypothesis 3: The later the time of CMS adoption by SMEs, the greater the influence of adopters' perceptions of mimetic motives on CMS implementation.

\subsubsection{Internal efficiency motives}

Firms are not deterministically governed by their institutional environment (Hillebrand et al., 2011). The argument that CMS adoption may be driven by efficiency considerations is well developed in the literature in respect to large firms. Less has been said about SMEs, although it has been suggested that cost reduction and profit maximization motives are significant 
(Battisti \& Perry, 2011). In regard of large firms, there is an established view that earlier adopters of voluntary standards are more likely to be motivated by the perceived intrinsic benefits of a practice. This assumption can be expanded to form the fourth hypothesis:

Hypothesis 4: The earlier the time of CMS adoption by SMEs, the greater the influence of adopters' perceptions of internal efficiency motives on CMS implementation.

\subsubsection{Commitment to CMS}

There is a suggestion that the years of implementation of a practice positively influence a firm's commitment to that practice (Delmas \& Montes-Sancho, 2007). To the extent that this is accurate, it may be expected that those SMEs that adopted CMS earlier should demonstrate their commitment through more complete implementation of CMS requirements. In turn, those SMEs that adopted CMS at later stages might not commit as fully to the standards' requirements and implement them symbolically. Hence, it is hypothesised that:

Hypothesis 5: The earlier the time of CMS adoption by SMEs, the greater the possibility for SMEs to fully commit to the CMS requirements.

\section{Method}

\subsection{Sample}

The sample was drawn from ISO 9001, ISO 14001 and OHSAS 18001 certified companies operating in the county of Attica, the most significant economic region of Greece, which accounts for half national GDP. Choosing a geographically limited sampling frame has the advantage of guaranteeing that all companies sampled share the similar cultural and institutional context. Thus, all firms contained within the sample are likely to face similar levels 
of scrutiny insofar as they conform to the same social and environmental demands (Long \& Driscoll, 2008).

Due to the absence of any official database of certified companies in Greece, data were collected through ICAP, QualityNet.gr ${ }^{1}$ and consultations with officials working for Greek certification bodies. The respondents were requested to confine their responses to only the period when all three CMS were operational within their firm. To ensure a high quality of responses, the key informant method was used. The survey was directed at managers responsible for the implementation of CMS, in line with previous studies (Aravind \& Christmann, 2011; Christmann \& Taylor, 2006). A total population of 828 certified SMEs were identified. The questionnaire was emailed to a subsample of 489 SMEs that had all three certifications. The questionnaire was compiled in English and translated into Greek, and from Greek back into English, with the help of bilingual native speakers, to ensure the authenticity of translation. The survey was pilot tested and the final version of the survey was distributed via both hard copy and web-based formats. To improve the response rate, the survey was followed by two reminders. Responses were anonymised to reduce the probability of biased answers. To ensure the validity of responses, the survey addressed predecessor information on questions regarding motivations to adopt CMS in prior years ${ }^{2}$. In total, 178 valid questionnaires were returned, securing a response rate of $36.4 \%$. This is above a typical response rate of largescale mail survey (Dillman, 2000) and, moreover, it compares favourably to other similar studies (Heras-Saizarbitoria and Boiral, 2013b; Jamali, 2010; Singh, 2015).

To evaluate the representativeness of the mailing sample, the non-response bias was estimated by comparing an early tranche of survey participants and a latter tranche. This method is widely used (Luo et al., 2009) and based on the assumption that late respondents of the survey (those 
who replied after the second reminder) are very similar to non-respondents, given that they would have fallen into that category had not the second reminder been mailed. Early versus late respondents of the survey were compared along the variables used in hypotheses testing. T-tests showed no significant differences suggesting sample representativeness and indicating that the survey's sample does not suffer from non-response bias (Heavey et al., 2009). The reliability of the self-reported data was assessed by randomly conducting follow-up telephone surveys with ten companies, chosen from the survey sample, with no deviation from previous responses identified.

Of the sample of 178 SMEs, the largest segment of respondents $(38.5 \%)$ operate in the service sector, including financial, insurance and real estate, followed by wholesale and retail trade $(33 \%)$ and manufacturing activities $(28.5 \%)^{3}$.

\subsection{Variables}

Later adopters will, by definition, implement CMS for a shorter period of time than earlier adopters. Hence, the dependent variable in this paper is Years of CMS implementation ${ }^{4}$ (YoI $\mathrm{I}_{\mathrm{CMS}}$ ) whereby the firm has been implementing the bundle of the three CSR related standards, namely ISO 9001, ISO 14001 and OHSAS 18001.

The independent variables refer to SMEs motives and SMEs commitment to the CMS requirements. SMEs motives incorporate the fourteen drivers most widely quoted in the literature as motives for CMS adoption (Bansal \& Hunter, 2003; Boiral, 2007; Castka \& Balzarova, 2007; Delmas \& Montes-Sancho, 2011; Gonzalez-Benito \& Gonzalez-Benito, 2005; King et al., 2005; Simpson et al., 2012; Singh et al., 2015). Respondents were asked to rate the influence of each driver on their decision to subscribe to a CMS on a five point likert 
scale $(1=$ not important, $5=$ very important). The fourteen variables were collapsed into four factors after conducting factor analysis (see Appendix). The reliability of each factor was assessed using Cronbach's alpha; as shown below, all factors had $\alpha>0.7$, thus indicating an adequate level of reliability of the survey items (Bagozzi et al., 1991; Nunnally, 1978):

- Influence of coercive motives: influence of customers' requirements; domestic market requirements; access to international markets; pressure from other companies $(\alpha=$ 0.809).

- Influence of normative motives: contribution of CMS to CSR; importance of CSR performance $(\alpha=0.786)$.

- Influence of mimetic motives: influence of governmental authorities; NGOs; EU; local community $(\alpha=0.833)$.

- Influence of internal efficiency motives: influence of greater productivity; cost savings; financial performance; sales' increase $(\alpha=0.848)$.

In order to capture the extent of commitment by SMEs to the substantial implementation of the three standards, the study adopted the methodology employed by Christmann and Taylor (2006) and Naveh and Marcus (2004). This involved asking managers: (a) to specify the degree to which SMEs use the CMS documents in their everyday activities (1=not at all, 5=to a large extent), measured by the variable daily use of the standards'documents; and, (b) if they change the content of the documents on the verge of external audits (reverse score) ( $1=$ not at all, $5=$ to a large extent), captured by the variable content change of the standard's documents. The rationale behind this latter variable is that those SMEs which apply the standards systematically are likely to make changes as required by their daily operation, whilst SMEs that adopt the standards for symbolic reasons are likely to only update documentation at the last minute to pass the annual certification audits. SMEs commitment was measured as the average of these 
two items. A low score indicates low commitment to CMS implementation (symbolic implementation) while a high score indicates high commitment to CMS implementation (substantial implementation). A Cronbach Alpha of 0.701 shows good reliability of the measure.

Sector affiliation is used as a control variable in response to suggestions expressed in the literature (King et al., 2005) that CMS may have more relevance to manufacturing firms than to those in other sectors, thus implying that the latter may be predisposed to the symbolic implementation of the standards. Size is also added as a control variable to address evidence from previous research indicating that SMEs might have problems in implementing CMS due to lack of resources (King \& Lenox, 2000). To control for firm size, the logarithm ${ }^{5}$ of the number of employees was used. Table 1 summarizes the measures used in the analysis.

\section{INSERT TABLE 1 ABOUT HERE}

\section{Analysis and results}

Multiple regression is used in order to predict the relationship between a continuous dependent variable (Years of CMS implementation) and several independent variables (Coercive motives, Normative motives, Mimetic motives, Internal efficiency motives, SMEs commitment), while controlling for two independent variables (Industry and Size). To ensure that the collected data are appropriate for multiple regression analysis, both normality and multicollinearity of the predictor variables were considered. To assess normality, the skewness of each measure was identified. It was established that all values fell within the acceptable range for skewness of between -1 and +1 (Hair et al., 1998). Regarding multicollinearity, no inter-factor correlation 
was found to be above 0.70 , indicating that multicollinearity did not seriously affect the results (Table 2). To diminish potential multicollinearity threats, the tolerance and Variance Inflation Factor (VIF) values of each individual predictor were examined. Their values ranged between 1.01 to 1.35 , which are well below the accepted level of 10.0 (Hair et al., 1998), thereby denoting the absence of multicollinearity.

The reliance upon self-reported data, derived from managers' responses, raises the question of common method variance (CMV). The potential presence of CMV was tested through the use of Harman's single factor test (Podsakoff et al., 2003). If CMV is present, a single factor emerges from the factor analysis or one general factor accounts for the majority of the variance in the variables. The test yielded four factors with Eigenvalues greater than 1.0 and indicated that the first factor accounted only for a minority of variance (19.8\%). This signifies that CMV is not of great concern in the data (Pérez-Nordtvedt et al., 2008).

\section{INSERT TABLE 2 ABOUT HERE}

Table 3 presents the results of the regression analysis. In order to separate the effects of the control and the independent variables, a baseline model was first estimated which included only the control variables Industry and Size. Their inclusion in the equation generated an overall non-significant model, $\mathrm{F}(2,175)=.793, \mathrm{p}=.454$, indicating that industry affiliation and size did not have any effect on the dependent variable Years of CMS implementation $\left(Y_{\text {oI }} I_{C M S}\right)$. By contrast, when SMEs motives and SMEs commitment were introduced into the equation, this produced an overall significant model, $\mathrm{F}(5,170)=14.166, \mathrm{p}<.001$. The results of the regression indicated that five predictors explained $34.2 \%$ of the variance of $Y_{O M S}\left(\mathrm{R}^{2}=.368\right.$, 
Adj. $\mathrm{R}^{2}=.342$ ). This is a typical effect size common in business studies (Cohen, 1988). Within our model the adoption motives with the most significant impact on YoI $_{\text {CMS }}$ are Coercive motives $(\mathrm{b}=-.246)$, followed by Mimetic motives $(\mathrm{b}=-.198)$, Normative motives $(\mathrm{b}=.183)$ and Internal efficiency motives $(\mathrm{b}=.166)$.

INSERT TABLE 3 ABOUT HERE

The findings of the econometric analysis provide evidence consistent with all five hypotheses formulated in this paper (see Table 4). More precisely, an inspection of the coefficients of the independent variables reveals that Coercive motives $(b=-.246, t=-3.472, p<.01)$ as well as Mimetic motives $(\mathrm{b}=-.198, \mathrm{t}=-2.821, \mathrm{p}<.01)$ are negatively related to YoI $_{C M S}$. This implies that later adopters might be more susceptible to these motives than earlier adopters. In turn, the coefficients of Normative motives $(\mathrm{b}=.183, \mathrm{t}=2.690, \mathrm{p}<.01)$ and Internal efficiency motives $(\mathrm{b}=.166, \mathrm{t}=2.395, \mathrm{p}<.05)$ indicate a positive relationship between these motives and $Y_{\text {oI }} I_{C M S}$. This suggests that earlier adopters might show more concern for normative and internal efficiency motives. Finally, SMEs commitment $(\mathrm{b}=.301, \mathrm{t}=4.514, \mathrm{p}<.001)$ shows a positive relationship between this variable and $Y_{\text {oI }} I_{C M S}$, thus indicating that greater commitment to the implementation of the requirements of CMS appears to characterise earlier rather than later adopters. Hence, the results of this analysis suggest that earlier adopters of CMS are more likely to implement the standards substantially in comparison to the later adopters. 


\section{Discussion}

The extant literature on the relationship between CSR and CMS in terms of motivation and implementation has a tendency to concentrate on larger firms and investigate the application of individual standards separately. Consequently, this paper offers a different perspective by analysing the behaviour of small and medium-sized firms that have subscribed to a bundle of CSR related CMS. This is an advance (Boiral, 2011; Rasche, 2009) on those studies which tend to consider the application of just one standard in isolation (Boiral \& Henri, 2012; Castka \& Prajogo, 2013; Heras-Saizarbitoria \& Boiral, 2013b; Iatridis and Kesidou, 2016; Lannelongue et al., 2013; Zailani et al., 2012). By shifting the focus towards firms which subscribe to multiple CSR related standards, we put in the limelight the behaviour of an important category of SMEs that demonstrate a more systematic, and possibly a more advanced, approach to managing their corporate responsibilities.

Regression analysis corroborates the theoretical arguments that underpin this research, demonstrating the overall validity of established views on the drivers behind the adoption of CMS. This is not an insignificant finding considering that there is a strong stream in the literature that suggests that attitudes to, and practices of, CSR in SMEs are appreciably different from those developed in large companies (Ciliberti et al., 2008; Enderle, 2004; Jamali et al., 2009; Perrini, 2006; Preuss \& Perschke, 2010; Russo \& Perrini, 2010; Sweeney, 2007). One important aspect of the debate is the role of formal tools such as social and ethical standards when applied in SMEs. These tools, it is argued, are developed with large firms in mind and therefore their implementation pattern in smaller firms may be different (Baumann-Pauly et 
al., 2013; Enderle, 2004; Spence et al., 2000). Our research demonstrates that, in fundamental respects, SMEs tend to react to CSR related CMS in a similar manner to larger firms, and are guided by similar institutional and economic motives, as is evident from the comparison of the behaviour of earlier and later adopters.

Our analysis indicates that the personal beliefs and values of the people running SMEs, who are usually also the owners, are particularly weighty drivers of CSR activities (Grayson, 2004; Lepoutre \& Heene, 2006; Vyakarnam et al., 1997). Hence, it may be conjectured that ownersmanagers with strong normative views on social responsibility of business are more likely to be found among earlier adopters of the standards. This conclusion is supported by Arya and Zhang (2009), who argued that larger firms with ethical motivations tend to be first movers in the adoption of CSR related practices. Our data indicates that this might be the case for SMEs as well. At the same time, our results are in a dissonance with the view expressed by Cordano et al. (2010) who argued that, in an SME context, normative pressures tend to increase with time. Our findings suggest that, with the passage of time, in the case of CMS, normative pressures lose significance and SMEs tend to adopt CSR related practices increasingly due to coercive and mimetic pressures.

Incorporating a time dimension into the analysis has allowed us to make a contribution to the literature on the comparative influence of the motives that drive SMEs to subscribe to CSR related standards. This literature usually assumes a static approach that does not account for changes that may occur over a period of time (e.g. Heras-Saizarbitoria et al., 2011; HerasSaizarbitoria \& Boiral, 2013b; Heras-Saizarbitoria, 2011; Singh et al., 2015). Our results suggest that, in the case of SMEs, the balance of power between motives shifts from normative 
and internal efficiency motives for earlier adopters to coercive and mimetic motives for later adopters.

A notable result is the finding that industry characteristics have no significant influence on a firm's behaviour towards CSR related CMS. This counters the conclusion, often drawn in the literature, that sector affiliation influences the degree of commitment to CMS requirements displayed by larger firms (Boiral, 2003). That SMEs behave differently may be a consequence of the difference in size, as the environmental and other impacts of individual small units of production are less noticeable than those produced by large firms, although the cumulative impact should be significant considering that in Europe alone SMEs amount to $99 \%$ of all firms (Spence et al., 2000).

In line with previous studies (Corbett, 2006; Delmas \& Montes-Sancho, 2007), this paper reveals a significant difference in the behaviour of earlier and later adopters. The latter have been found to be less committed to CMS requirements. By contrast, earlier adopters of CMS exhibit behaviour that implies a more substantial integration of standards in their operations. These results show that, although SMEs adopting CMS are forced to share common practices, this does not necessarily lead to the internalisation of corporate responsibility into business strategy. These findings are in line with a burgeoning stream of research that focuses on large companies, and which challenges the assumption that there is a linear relationship between institutions like CMS and socially responsible business conduct (Allur et al., 2014; HerasSaizarbitoria \& Boiral, 2013b; Nair \& Prajogo, 2009; Perez-Batres et al., 2012). We found that, equally in an SME context, the implementation of CMS varies, leading to dissimilar levels of CSR embeddedness into business strategy. 
For economies such as Greece, in which the vast majority of CMS participants are later adopters (ISO, 2014), the finding that this category of CMS adopters tends to apply the standards symbolically is significant. It indicates that the majority of SMEs seek to employ CMS standards in a manner that allows to reconcile the traditional business model with limited social and environmental performance. In other words, they prefer to stick to the 'business as usual' scenario and do not make serious attempts to use CMS as a means of advancing their social and environmental performance.

Finally, given that CSR practices, including CMS, are voluntary and based on self-regulation, the results outlined in this paper cast doubt upon the proposition that socially responsible business practices can be best implemented through self-regulatory tools (Lenox \& Nash, 2003; Levy \& Kaplan, 2008). The paper, therefore, offers support to research that adopts a more sceptical approach towards the role of self-regulation as a driver of corporate responsible practices (Locke et al., 2013; Toffel et al., 2013) and towards the effectiveness of selfregulation in general. The revealed distinction between earlier and later adopters suggests that, at some point in time, any form of process based self-regulation, not supported by sanctions, may be expected to enter a stage whereby participation becomes a passive act, decoupled from implementation, thus drastically reducing its effectiveness.

\section{Conclusions and directions for future research}

Apart from its theoretical contribution, the paper's results have implications for policy-makers and practitioners. Regarding the use of self-regulatory approaches to encourage CSR, it has been shown that these tools may not be as effective as their supporters may suggest. Accordingly, regulators should consider playing a more active role in stimulating and 
encouraging CSR. Given the apparent reluctance of Western states to enforce regulation intended to promote CSR, and the constraints imposed by a globalized business environment (Bauman, 2007), one possible solution would be for governments to collaborate with industry associations and work towards improving existing self-regulatory tools. The authors agree with Campbell (2007) that this may help governments to share the costs related with the application of CSR practices, whilst establishing strict monitoring and sanction mechanisms to ensure that such practices do not become subject to adverse selection.

The paper's results have additional implications for those managers who use CMS as a criterion of selecting their business partners. It has been demonstrated that certification per se is not sufficient to establish the CSR credentials of the firm. Instead, information concerning the actual implementation of the standard would provide a superior benchmark for selection.

There are a number of limitations to this study pointing towards possible avenues for future research. First, testing the study's propositions in the context of a single country minimized influences exerted by the environment constant, but weakened the wider applicability of the results. Due to cultural influences on organizations and, by extension, on CMS implementation, an interesting development of this study could be a cross-country research, analysing institutional and cultural influences on why and how businesses adopt CSR practices such as CMS. This would assist in testing further the robustness of the current theoretical predictions and investigate whether firms' motives for adopting CMS and way in which firms apply these standards vary in different cultural contexts.

Second, in line with previous literature (Christmann \& Taylor, 2006; Oskarsson \& von Malmborg, 2005), this paper assumed that because the structure, the implementation process 
and the audit requirements of ISO 9001, ISO 14001 and OHSAS 18001 are similar, firms were likely to exhibit similar patterns of behaviour when implementing all of these standards. Nonetheless, it would prove an interesting extension of this study to investigate whether this is, indeed, the case.

Furthermore, another potential avenue for future research could be to include in the analysis of earlier and later adopters of CMS any decertification trends found between these two groups. Although such trends do not appear to be significant at the moment, as suggested by the latest ISO survey, it would be interesting nonetheless to investigate the causes of decertification and their possible effect on the behaviour of SMEs.

Finally, the measures used in this paper are not exhaustive. They allowed valuable insights in the evaluation of corporate attitudes towards CMS, but it would be wrong to pretend that they have fully captured the various facets of the motivations of firms relating to the adoption of such standards and how firms choose to implement them. Future studies could contribute by introducing additional measures to further test the robustness of current CSR theory.

The analysis contained within this paper reinforces the view that the adoption of CMS by SMEs is driven by coercive and mimetic motives rather than by normative or internal efficiency motives. Moreover, the paper's findings indicate that, in contrast to earlier adopters, later adopters of CMS might not be so much interested in managerial effectiveness as in seeking to extract benefits of a different kind, for example, to enhance their own reputation. This evidence suggests that, in Greece, CMS have not diffused among companies so much because of their potential to assist firms in applying CSR related practices, but mostly due to market and peer pressures. These results are significant in emphasizing the fact that in the domain of CSR, 
ostensibly so exposed to public scrutiny, market stimuli are still a prime force behind the firm's decision to subscribe to CMS.

\section{Notes}

\footnotetext{
${ }^{1}$ These two organizations publish lists with the names of certified companies in Greece.

${ }^{2}$ To address the situation in which the manager responsible for the implementation of CMS had been replaced, information on their predecessor/s was requested. Questions concerning predecessor/s were: 'Length in position before leaving'; 'Reason for leaving'; 'Do you believe that your company's motivations for adopting CMS might have been different when you were not employed in the company?; and 'Do you think that your company implements the CMS differently compared to when your predecessor was in charge?' Only in six cases was the reply to at least one of the last two questions in the affirmative and these were excluded from the paper's sample. ${ }^{3}$ Classification according to the Standard Industrial Classification (SIC) System.

${ }^{4}$ Certification year is up to mid-2014.

${ }^{5} \mathrm{~A}$ transformation was necessary to achieve normal distribution.
}

\section{Acknowledgements}

The authors would like to thank the associate editor of Business Ethics Quarterly, Jerry Goodstein and the three anonymous reviewers for their insightful comments on earlier versions of the manuscript. 


\section{References}

Agan, Y., Acar, M. F., \& Borodin, A. 2013. Drivers of environmental processes and their impact on performance: A study of Turkish SMEs. Journal of Cleaner Production, 51(0): 23-33.

Aguilera, R. V., Rupp, D. E., Williams, C. A., \& Ganapathi, J. 2007. Putting the S back in corporate social responsibility: A multilevel theory of social change in organizations. Academy of Management Review, 32(3): 836-863.

Allur, E., Heras-Saizarbitoria, I., \& Casadesús, M. 2014. Internalization of ISO 9001: A longitudinal survey. Industrial Management \& Data Systems, 114(6): 872-885.

Aravind, D. \& Christmann, P. 2011. Decoupling of standard implementation from certification: Does quality of ISO 14001 implementation affect facilities' environmental performance? Business Ethics Quarterly, 21(1): 73-102.

Arya, B. \& Salk, J. E. 2006. Cross-sector alliance learning and effectiveness of voluntary codes of corporate social responsibility. Business Ethics Quarterly, 16(5): 211-234.

Arya, B. \& Zhang, G. 2009. Institutional reforms and investor reactions to CSR announcements: Evidence from an emerging economy. Journal of Management Studies, 46(7): 1089-1112.

Bagozzi, R. P., Youjae, Y., \& Phillips, L. W. 1991. Assessing construct validity in organizational research. Administrative Science Quarterly, 36(3): 421-458.

Bansal, P. \& Bogner, W. C. 2002. Deciding on ISO 14001: Economics, institutions, and context. Long Range Planning, 35(3): 269-290.

Bansal, P. \& Hunter, T. 2003. Strategic explanations for the early adoption of ISO 14001. Journal of Business Ethics, 46(3): 289-299. 
Battisti, M. \& Perry, M. 2011. Walking the talk? Environmental responsibility from the perspective of small-business owners. Corporate Social Responsibility and Environmental Management, 18: 172-185.

Baum, J. A. C. \& Oliver, C. 1992. Institutional embeddedness and the dynamics of organizational populations. 57(4): 540-559.

Bauman, Z. 2007. Postmodern ethics. Oxford: Blackwell Publishing.

Baumann-Pauly, D., Wickert, C., Spence, L., \& Scherer, A. 2013. Organizing corporate social responsibility in small and large firms: Size matters. Journal of Business Ethics, 115(4): 693-705.

Behnam, M. \& MacLean, T. 2011. Where is the accountability in international accountability standards? A decoupling perspective. Business Ethics Quarterly, 21(1): 45-72.

Biazzo, S. \& Bernardi, G. 2003. Process management practices and quality systems standards: Risks and opportunities of the new ISO 9001 certification. Business Process Management Journal, 9(2): 149 - 169.

Boiral, O. 2003. The certification of corporate conduct: Issues and prospects. International Labour Review, 142(3): 317-340.

Boiral, O. 2007. Corporate greening through ISO 14001: A rational myth? Organization Science, 18(1): 127-162.

Boiral, O. \& Amara, N. 2009. Paradoxes of ISO 9000 performance: A configurational approach. The Quality Management Journal, 16(3): 36-60.

Boiral, O. 2011. Managing with ISO systems: Lessons from practice. Long Range Planning, 44(3): 197-220.

Boiral, O. \& Henri, J.-F. 2012. Modelling the impact of ISO 14001 on environmental performance: A comparative approach. Journal of Environmental Management, 99(0): 84-97. 
Brunsson, N., Jacobsson, B., \& Associates. 2005. A World of standards (2nd ed.). Oxford: Oxford University Press.

Brunsson, N., Rasche, A., \& Seidl, D. 2012. The dynamics of standardization: Three perspectives on standards in organization studies. Organization Studies, 33(5-6): 613632.

BSI. 2013. Health \& Safety OHSAS 18001. London, UK.

Campbell, J. L. 2007. Why would corporations behave in socially responsible ways? An institutional theory of corporate social responsibility. Academy of Management Review, 32(3): 946-967.

Cannon, T. 2012. Corporate responsibility. Governance, compliance and ethics in a sustainable environment ( 2 ed.). Harlow: Pearson

Castka, P. \& Balzarova, M. A. 2007. A critical look on quality through CSR lenses: Key challenges stemming from the development of ISO26000. The International Journal of Quality \& Reliability Management, 24(7): 738-752.

Castka, P. \& Prajogo, D. 2013. The effect of pressure from secondary stakeholders on the internalization of ISO 14001. Journal of Cleaner Production, 47(0): 245-252.

Christmann, P. \& Taylor, G. 2006. Firm self-regulation through international certifiable standards: Determinants of symbolic versus substantive implementation. Journal of International Business Studies, 37(6): 863-878.

Ciliberti, F., Pontrandolfo, P., \& Scozzi, B. 2008. Integrating corporate social responsibility in the management of supply chains. In C. Wankel (Ed.), 21st century management: A reference handbook: I-116-I-127. Thousand Oaks, CA: SAGE Publications.

Claessens, S. \& Yurtoglu, B. B. 2012. Corporate governance in emerging markets: A survey. Emerging Markets Review, 15: 1-33. 
Cohen, J. 1988. Statistical power and analysis for the behavioral sciences (2nd ed.). Hillsdale NJ: Lawrence Erlbaum Associates.

Corbett, C., J. . 2006. Global diffusion of ISO 9000 certification through supply chains. Manufacturing \& Service Operations Management, 8(4): 330-350.

Cordano, M., Marshall, R. S., \& Silverman, M. 2010. How do small and medium enterprises go "green"? A study of environmental management programs in the U.S. wine industry. Journal of Business Ethics, 92(3): 463-478.

Cote, R., Booth, A., \& Louis, B. 2006. Eco-efficiency and SMEs in Nova Scotia, Canada. Journal of Cleaner Production, 14: 542-550.

Delmas, M. A. \& Montes-Sancho, M. J. 2007. Voluntary agreements to improve environmental quality: Are late joiners the free riders?, Vol. 2008. Santa Barbara: Working Paper 07, University of California.

Delmas, M. A. \& Montes-Sancho, M. J. 2011. An institutional perspective on the diffusion of international management system standards. Business Ethics Quarterly, 21(1): 10521081.

Dillman, D. A. 2000. Mail and internet surveys: The tailored design method (2nd ed.). New York: John Wiley \& Sons.

DiMaggio, J., P., \& Powell, W. W. 1983. The iron cage revisited: Institutional isomorphism and collective rationality in organizational fields. American Sociological Review, 48(2): 147-160.

Enderle, G. 2004. Global competition and corporate responsibilities of small and medium-sized enterprises. Business Ethics: A European Review, 13(1): 50-63.

European Commission. 2003. Mapping instruments for corporate social responsibility. Luxembourg: European Commission. 
European Communities. 2002. ENSR European network for SME research. European SMEs and Social and Environmental Responsibility. Luxembourg: Office for Official Publications of the European Communities.

Göbbels, M. \& Jonker, J. 2003. AA 1000 and SA 8000 compared: A systematic comparison of contemporary accountability standards. Managerial Auditing Journal, 18(1): 54 - 58.

Gonzalez-Benito, J. \& Gonzalez-Benito, O. 2005. An analysis of the relationship between environmental motivations and ISO14001 certification. British Journal of Management, 16(2): 133-148.

Grayson, D. 2004. How CSR contributes to the competitiveness of Europe in a more sustainable world. Netherlands: The World Bank Institute and the CSR Resource Centre.

Guller, I., Guillen, M. F., \& Macpherson, J. M. 2002. Global competition, institutions, and the diffusion of organizational practices: The international spread of ISO 9000 quality certificates. Administrative Science Quarterly, 47(2): 207-232.

Guoyou, Q., Saixing, Z., Xiaodong, L., \& Chiming, T. 2012. Role of internalization process in defining the relationship between ISO 14001 certification and corporate environmental performance. Corporate Social Responsibility and Environmental Management, 19(3): 129-140.

Hair, J., Anderson, R., Tathman, R., \& Black, W. 1998. Multivariate data analysis (5th ed.). Upper Saddle River, NJ: Prentice Hall.

Heavey, C., Simsek, Z., Roche, F., \& Kelly, A. 2009. Decision comprehensiveness and corporate entrepreneurship: The moderating role of managerial uncertainty preferences and environmental dynamism. Journal of Management Studies, 46(8): 1289-1314.

Hemingway, C., A. \& Maclagan, P., W. . 2004. Managers' personal values as drivers of corporate social responsibility. Journal of Business Ethics, 50(1): 33. 
Heras-Saizarbitoria, I., Arana, G., \& Molina-Azorín, J. F. 2011. Do drivers matter for the benefits of ISO 14001? International Journal of Operations \& Production Management, 31(2): 192 - 216.

Heras-Saizarbitoria, I. \& Boiral, O. 2013a. ISO 9001 and ISO 14001: Towards a research agenda on management system standards. International Journal of Management Reviews, 15(1): 47-65.

Heras-Saizarbitoria, I. \& Boiral, O. 2013b. Symbolic adoption of ISO 9000 in small and medium-sized enterprises: The role of internal contingencies. International Small Business Journal.

Heras-Saizarbitoria, I. 2011. Internalization of ISO 9000: An exploratory study. Industrial Management \& Data Systems, 111(8): 1214-1237.

Hillebrand, B., Nijholt, J., \& Nijssen, E. 2011. Exploring CRM effectiveness: An institutional theory perspective. Journal of the Academy of Marketing Science, 39(4): 592-608.

Hodgson, D. \& Cicmil, S. 2007. The Politics of standards in modern management: Making 'the project' a reality. Journal of Management Studies, 44(3): 431-450.

Hoffman, A., J. . 1999. Institutional evolution and change: Environmentalism and the U.S. chemical industry. Academy of Management Journal, 42(4): 351-371.

Iatridis, K. and Kesidou, E. 2016. What drives substantive versus symbolic implementation of ISO14001 in a time of economic crisis? Insights from Greek manufacturing companies. Journal of Business Ethics. DOI: 10.1007/s10551-016-3019-8.

ISO. 2009. Management Standards: Geneva, ISO.

ISO. 2010. Social responsibility - Discovering ISO 26000. Geneva: ISO.

ISO. 2014. The ISO survey. Geneva.

Jamali, D., Zanhour, M., \& Keshishian, T. 2009. Peculiar strengths and relational attributes of SMEs in the context of CSR. Journal of Business Ethics, 87(3): 355-377. 
Jamali, D. 2010. MNCs and international accountability standards through an institutional lens: Evidence of symbolic conformity or decoupling. Journal of Business Ethics, 95(4): 617-640.

Jiang, R. J. \& Bansal, P. 2003. Seeing the need for ISO 14001. Journal of Management Studies, 40(4): 1047-1067.

King, A., Lenox, M., \& Terlaak, A. 2005. The strategic use of decentralized institutions: Exploring certification with the ISO 14001 management standard. Academy of Management Journal, 48(6): 1091-1106.

King, A. A. \& Lenox, M. J. 2000. Industry self-regulation without sanctions: The chemical industry's responsible care program. Academy of Management Journal, 43(4): 698716.

Lannelongue, G., Gonzalez-Benito, O., \& Gonzalez-Benito, J. 2013. Environmental motivations: The pathway to complete environmental management. Journal of Business Ethics: 1-13.

Lenox, M. J. \& Nash, J. 2003. Industry self-regulation and adverse selection: A comparison across four trade associations programs. Business Strategy and the Environment, 12(6): 343-356.

Lepoutre, J. \& Heene, A. 2006. Investigating the impact of firm size on small business social responsibility: A critical review. Journal of Business Ethics, 67(3): 257-273.

Levy, D. L. \& Kaplan, R. 2008. Corporate social responsibility and theories of global governance. Strategic contestation in global issue arenas. In A. Crane \& A. McWilliams \& D. Matten \& J. Moon \& D. Siegel (Eds.), The oxford handbook of corporate social responsibility: 432-451. Oxford: Oxford University Press. 
Lewis, K. V. \& Cassells, S. 2010. Barriers and drivers for environmental practice uptake in SMEs: A New Zealand perspective. International Journal of Business Studies, 18(1): $7-21$.

Locke, R. M., Rissing, B. A., \& Pal, T. 2013. Complements or substitutes? Private codes, state regulation and the enforcement of labour standards in global supply chains. British Journal of Industrial Relations, 51(3): 519-552.

Long, B. S. \& Driscoll, C. 2008. Codes of ethics and the pursuit of organizational legitimacy: Theoretical and empirical contributions. Journal of Business Ethics, 77(2): 173-189.

Luo, Y., Liu, Y., \& Xue, J. 2009. Relationship investment and channel performance: An analysis of mediating forces. The Journal of Management Studies, 46(7): 1113-1137.

Mandl, I. \& Dorr, A. 2007. CSR and competitiveness. European SMEs' good practice. Consolidated European Report. Vienna: Austrian Institute for SME Research.

Marano, V. \& Kostova, T. 2015. Unpacking the institutional complexity in adoption of CSR practices in multinational enterprises. Journal of Management Studies. DOI: 10.1111/joms.12124.

Montiel, I. \& Husted, B. 2009. The adoption of voluntary environmental management programs in Mexico: First movers as institutional entrepreneurs. Journal of Business Ethics, 88: 349-363.

Mori, Y. \& Welch, E. W. 2008. The ISO 14001 environmental management standard in Japan: Results from a national survey of facilities in four industries. Journal of Environmental Planning and Management, 51(3): 421-445.

Mueller, M., dos Santos, V., \& Seuring, S. 2009. The contribution of environmental and social standards towards ensuring legitimacy in supply chain governance. Journal of Business Ethics, 89(4): 509-523. 
Murillo, D. \& Lozano, J. P. 2006. CSR and SMEs: A bet for business excellence. Barcelona: ESADE.

Nair, A. \& Prajogo, D. 2009. Internalisation of ISO 9000 standards: The antecedent role of functionalist and institutionalist drivers and performance implications. International Journal of Production Research, 47: 4545-4568.

Naveh, E., Marcus, A., \& Hyoung Koo, M. 2004. Implementing ISO 9000: Performance improvement by first or second movers. International Journal of Production Research, 42(9): 1843-1863.

Naveh, E. \& Marcus, A. A. 2004. When does the ISO 9000 quality assurance standard lead to performance improvement? Assimilation and going beyond. IEEE Transactions on Engineering Management Science, 51(3): 352-363.

Neumayer, E. \& Perkins, R. 2005. Uneven geographies of organizational practice: Explaining the cross-national transfer and diffusion of ISO 9000 Economic geography, 81(3): 237259.

Nunnally, J. C. 1978. Psycometric theory (2nd ed.). New York: McGraw-Hill.

OECD. 2009. Annual report on the OECD guidelines for multinational enterprises 2008. Employment and industrial relations. Paris: OECD Publishing.

Oskarsson, K. \& von Malmborg, F. 2005. Integrated management systems as a corporate response to sustainable development. Corporate Social Responsibility and Environmental Management, 12: 121-128.

Palazzo, G. \& Scherer, A. G. 2006. Corporate legitimacy as deliberation: A communicative framework. Journal of Business Ethics, 66(1): 71-88.

Perez-Batres, L., Doh, J., Miller, V., \& Pisani, M. 2012. Stakeholder pressures as determinants of CSR strategic choice: Why do firms choose symbolic versus substantive selfregulatory codes of conduct? Journal of Business Ethics, 110(2): 157-172. 
Pérez-Nordtvedt, L., Kedia, B., Datta, D., \& Rasheed, A. 2008. Effectiveness and efficiency of cross-border knowledge transfer: An empirical examination. Journal of Management Studies, 45(4): 714-744.

Perrini, F. 2006. SMEs and CSR theory: Evidence and implications from an Italian perspective Journal of Business Ethics, 67(3): 305-316.

Perrini, F. \& Minoja, M. 2008. Strategizing corporate social responsibility: Evidence from an Italian medium-sized, family-owned company. Business Ethics: A European Review, 17(1): 47-63.

Podsakoff, P. M., Lee, J.-Y., MacKenzie, S. B., \& Podsakoff, N. P. 2003. Common method biases in behavioral research: A critical review of the literature and recommended remedies. Journal of Applied Psychology, 88(5): 879-903.

Potoski, M. \& Prakash, A. 2004. Regulatory convergence in nongovernmental regimes? Crossnational adoption of ISO 14001 certifications. Journal of Politics, 66(3): 885-905.

Potoski, M. \& Prakash, A. 2013. Do voluntary programs reduce pollution? Examining ISO 14001's effectiveness across countries. Policy Studies Journal, 41(2): 273-294.

Preuss, L. \& Perschke, J. 2010. Slipstreaming the larger boats: Social responsibility in mediumsized businesses. Journal of Business Ethics, 92(4): 531-551.

Rasche, A. 2009. Toward a model to compare and analyze accountability standards: The case of the UN global compact. . Corporate Social Responsibility and Environmental Management, 16(4): 192-205.

Rasche, A. 2010. The limits of corporate responsibility standards. Business Ethics - A European Review, 19(3): 280-291.

Rivera, J., De Leon, P., \& Koerber, C. 2006. Is greener whiter yet? The sustainable slopes program after five years. Policy Studies Journal, 34(2): 195-221. 
Russo, A. \& Perrini, F. 2010. Investigating stakeholder theory and social capital: CSR in large firms and SMEs. Journal of Business Ethics, 91(2): 207-221.

Salomone, R. 2008. Integrated management systems: Experiences in Italian organizations. Journal of Cleaner Production, 16: 1786-1806.

Schaefer, A. 2007. Contrasting institutional and performance accounts of environmental management systems: Three case studies in the UK water \& sewerage industry. Journal of Management Studies, 44(4): 506-535.

Scott, W. R. 2001. Institutions and organizations (2nd ed.). Thousand Oaks, CA: Sage.

Simpson, D., Power, D., \& Klassen, R. 2012. When one size does not fit all: A problem of fit rather than failure for voluntary management standards. Journal of Business Ethics, 110(1): 85-95.

Singh, N., Jain, S., \& Sharma, P. 2015. Motivations for implementing environmental management practices in Indian industries. Ecological Economics, 109(0): 1-8.

Spence, L. J., Jeurissen, R., \& Rutherfoord, R. 2000. Small business and the environment in the UK and the Netherlands: Toward stakeholder cooperation. Business Ethics Quarterly, 10(04): 945-965.

Sweeney, L. 2007. Corporate social responsibility in Ireland: Barriers and opportunities experienced by SMEs when undertaking CSR. Corporate Governance, 7(4): 516-523.

Tencati, A., Russo, A., \& Quaglia, V. 2008. Unintended consequences of CSR: Protectionism and collateral damage in global supply chains: the case of Vietnam. Corporate Governance, 8(4): 518-531.

Terlaak, A. 2007a. Order without law? The role of certified management standards in shaping socially desired firm behaviors. Academy of Management Review, 32(3): 968-985. 
Terlaak, A. 2007b. Satisfying signaling: Corporate social strategy and certified management standards, Academy of Management 2007 Annual Meeting 1-6. Philadelphia: Academy of Management.

Toffel, M. W., Short, J. L., \& Ouellet, M. 2013. Codes in context: How states, markets, and civil society shape adherence to global labor standards. Harvard: Working Paper 13045, Harvard Business School.

Tolbert, P. S. \& Zucker, L. G. 1983. Institutional sources of change in the formal structure of organizations: The diffusion of civil service reform, 1880-1935. Administrative Science Quarterly, 28(1 ): 22-39.

USCIB; Corporate Responsibility Initiatives;

http://www.uscib.org/index.asp?documentID=2598; 24 October 2013.

Vázquez-Carrasco, R. \& López-Pérez, M. E. 2013. Small \& medium-sized enterprises and corporate social responsibility: A systematic review of the literature. Quality $\&$ Quantity, 47(6): 3205-3218.

von Weltzien Høivik, H. \& Shankar, D. 2011. How can SMEs in a cluster respond to global demands for corporate responsibility? Journal of Business Ethics, 101(2): 175-195.

Vyakarnam, S., Bailey, A., Myers, A., \& Burnett, D. 1997. Towards an understanding of ethical behaviour in small firms. Journal of Business Ethics, 16(15): 1625-1636.

Wijen, F. 2014. Means versus ends in opaque institutional fields: Trading off compliance and achievement in sustainability standard adoption. Academy of Management Review, 39(3): 302-323.

Zailani, S. H. M., Eltayeb, T. K., Hsu, C.-C., \& Tan, K. C. 2012. The impact of external institutional drivers and internal strategy on environmental performance.

International Journal of Operations \& Production Management, 32(6): 721-745. 


\section{Appendix: Factor loadings for pressures relating to years of CMS implementation}

\begin{tabular}{lcccc}
\hline & Factor 1 & Factor 2 & Factor 3 & Factor 4 \\
Item & $\begin{array}{c}\text { Coercive } \\
\text { Motives }\end{array}$ & $\begin{array}{c}\text { Normative } \\
\text { Motives }\end{array}$ & $\begin{array}{c}\text { Mimetic } \\
\text { Motives }\end{array}$ & $\begin{array}{c}\text { Internal } \\
\text { efficiency } \\
\text { Motives }\end{array}$ \\
\hline Importance of CSR performance & & & & -.074 \\
Influence of acknowledging social & .033 & $\mathbf{. 9 0 4}$ & .111 & .022 \\
responsibility & .096 & $\mathbf{. 8 5 9}$ & .261 & \\
Influence of Local Community & & & & -.192 \\
Influence of Governmental Authorities & .083 & .207 & $\mathbf{. 7 2 3}$ & -.069 \\
Influence of EU & .069 & .145 & $\mathbf{. 8 8 5}$ & -.056 \\
Influence of NGOs & .244 & .066 & $\mathbf{. 7 1 8}$ & -.109 \\
Influence of Companies & .131 & .060 & $\mathbf{. 8 2 3}$ & -.133 \\
Influence of intl. markets & $\mathbf{. 8 0 6}$ & -.083 & .117 & -.058 \\
Influence of domestic markets &. $\mathbf{7 3 4}$ & .041 & .221 & -.085 \\
Influence of Customers & $\mathbf{. 7 9 4}$ & .102 & .118 & -.297 \\
Influence of Sales &. $\mathbf{7 4 9}$ & .127 & .043 & $\mathbf{. 6 6 3}$ \\
Influence of Cost Savings & -.362 & -.080 & -.158 & $\mathbf{. 8 5 2}$ \\
Influence of Productivity & -.127 & .018 & -.119 & $\mathbf{. 8 9 9}$ \\
Influence of Financial Performance & -.023 & .049 & .005 & $\mathbf{. 7 8 2}$ \\
& -.154 & -.102 & -.184 & \\
\hline & & & & \\
\hline
\end{tabular}

Note: Bold indicates the highest loadings 
Table 1: Measures used in the analysis

\section{Dependent Variable}

Years of CMS implementation Measured Variable

Survey Question

The number of years a firm implements a CMS

For how long have you been implementing the standard/s?

\section{Independent Variables}

\begin{tabular}{|c|c|c|c|}
\hline \multirow{4}{*}{ 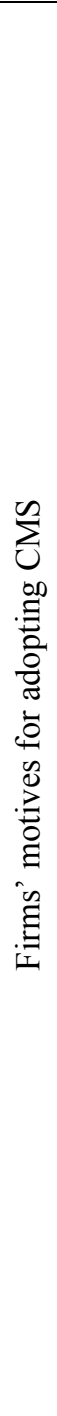 } & Coercive motives & $\begin{array}{l}\text { Influence of coercive motives in a SME's } \\
\text { decision to adopt CMS }\end{array}$ & $\begin{array}{l}\text { How would you rate the influence of the following factors in your decision to adopt and } \\
\text { implement the three certified management standards? } \\
\text { (i) Pressure from other companies, (ii) Satisfaction of domestic market requirements, } \\
\text { (iii) Access to international markets, (vi) Satisfaction of customer requirements } \\
\text { (1) Not important, (2) Of little importance, (3) Some importance, (4) Important, (5) Very } \\
\text { important }\end{array}$ \\
\hline & Normative motives & $\begin{array}{l}\text { Influence of normative motives in a SME's } \\
\text { decision to adopt CMS }\end{array}$ & $\begin{array}{l}\text { How would you rate the standards' contribution to CSR? } \\
\text { How would you rate the following statement? 'It is crucial that companies commit } \\
\text { themselves to a good CSR performance, even if this entails lower profits' } \\
\text { (1) Not important, (2) Of little importance, (3) Some importance, (4) Important, (5) Very } \\
\text { important }\end{array}$ \\
\hline & Mimetic motives & $\begin{array}{l}\text { Influence of mimetic motives in a SME's } \\
\text { decision to adopt CMS }\end{array}$ & $\begin{array}{l}\text { How would you rate the influence of the following factors in your decision to adopt and } \\
\text { implement the three certified management standards? } \\
\text { (i) Improved relations with local community, (ii) Improved relations with governmental } \\
\text { authorities, (iii) Satisfaction of EU requirements, (iv) Improved relations with NGOs } \\
\text { (1) Not important, (2) Of little importance, (3) Some importance, (4) Important, (5) Very } \\
\text { important }\end{array}$ \\
\hline & $\begin{array}{l}\text { Internal efficiency } \\
\text { motives }\end{array}$ & $\begin{array}{l}\text { Influence of internal efficiency motives in a } \\
\text { SME's decision to adopt CMS }\end{array}$ & $\begin{array}{l}\text { How would you rate the influence of the following factors in your decision to adopt and } \\
\text { implement the three certified management standards? } \\
\text { (i) Increase in sales, (ii) Cost Savings, (iii) Greater productivity, (iv) Improved financial } \\
\text { performance } \\
\text { (1) Not important, (2) Of little importance, (3) Some importance, (4) Important, (5) Very } \\
\text { important }\end{array}$ \\
\hline
\end{tabular}




\begin{tabular}{|c|c|c|c|}
\hline \multirow{2}{*}{ 诖 } & \multirow{2}{*}{$\begin{array}{l}\text { Daily use of the standard's } \\
\text { documents } \\
\text { Content change }\end{array}$} & $\begin{array}{l}\text { The SME uses the standards' documents on a } \\
\text { daily basis }\end{array}$ & $\begin{array}{l}\text { With reference to standards' implementation, please state to what extent the documents } \\
\text { created for the purpose of the management systems are used in daily practice. (1)Not at } \\
\text { all, (2)Very little, (3) To some extent, (4) To a large extent, (5) To a very large extent }\end{array}$ \\
\hline & & $\begin{array}{l}\text { The SME changes the content of the standards' } \\
\text { documents' prior to external audit }\end{array}$ & $\begin{array}{l}\text { With reference to standards' implementation, please state to what extent the content of } \\
\text { the documents changes pending the external audit. (1) Not at all, (2) Very little, (3) To } \\
\text { some extent, (4) To a large extent, (5) To a very large extent }\end{array}$ \\
\hline \multicolumn{4}{|c|}{ Control variable } \\
\hline $\begin{array}{l}\overparen{\Xi} \\
\stackrel{0}{\Xi} \\
\stackrel{\Xi}{\Xi}\end{array}$ & Industry & Industry sector & $\begin{array}{l}\text { Please state the industry your company belongs to. } \\
\text { 1=Service sector- including financial, insurance and real estate; } 2=\text { Whole sale and retail } \\
\text { trade; } 3=\text { Manufacturing, mining and quarrying, and construction activities }\end{array}$ \\
\hline$\stackrel{\stackrel{N}{N}}{i s}$ & Employees & The number of employees a company has & Please indicate the number of employees working in your company. \\
\hline
\end{tabular}


Table 2: Descriptive statistics and correlation analysis $(n=178)$

\begin{tabular}{|c|c|c|c|c|c|c|c|c|c|c|}
\hline Variables & Mean & SD & 1 & 2 & 3 & 4 & 5 & 6 & 7 & 8 \\
\hline Years of CMS implementation & 4.73 & 2.210 & 1 & & & & & & & \\
\hline Industry & 1.90 & .851 & -.060 & 1 & & & & & & \\
\hline LogEmployees & 3.38 & 1.105 & -.079 & .096 & 1 & & $\cdot$ & & & \\
\hline Influence of coercive motives & 2.11 & .912 & $-.390 * *$ & -.038 & -.176 & 1 & & & & \\
\hline Influence of normative motives & 3.31 & 1.042 & $.129 *$ & $-.142 *$ & -.039 & $.160 *$ & 1 & & & \\
\hline Influence of mimetic motives & 2.96 & 1.096 & $-.249 * *$ & .022 & -.021 & $.341^{* *}$ & $.353^{* *}$ & 1 & & \\
\hline Influence of internal efficiency motives & 3.37 & .972 & $.369 * *$ & -.100 & .037 & $-.383^{* *}$ & -.104 & $-.291 * *$ & 1 & \\
\hline SMEs commitment to CMS & 2.78 & 1.043 & .431 ** & -.075 & -.044 & $-.206^{* *}$ & $.231 * *$ & .044 & $.250 * *$ & 1 \\
\hline
\end{tabular}

Table 3: Regression results $(\mathbf{N}=178)$

\begin{tabular}{|c|c|c|}
\hline & \multicolumn{2}{|c|}{ Dependent variable YoI $_{\mathrm{CMS}}$} \\
\hline & $\begin{array}{c}\text { Model 1 } \\
\text { (Control variables only) }\end{array}$ & $\begin{array}{c}\text { Model } 2 \\
\text { (Full model) }\end{array}$ \\
\hline Intercept & $\begin{array}{l}5.489 * * \\
(.625) \\
\end{array}$ & $\begin{array}{l}3.545 * * \\
(1.106) \\
\end{array}$ \\
\hline \multicolumn{3}{|l|}{ Control Variable } \\
\hline Industry & $\begin{array}{l}-.053 \\
(.196)\end{array}$ & $\begin{array}{c}.011 \\
(.162)\end{array}$ \\
\hline Size (LogEmployees) & $\begin{array}{l}-.074 \\
(.151)\end{array}$ & $\begin{array}{l}-11.3 \\
(.125)\end{array}$ \\
\hline \multicolumn{3}{|l|}{ Independent variables } \\
\hline Coercive motives & & $\begin{array}{l}-.246 * * \\
(.172)\end{array}$ \\
\hline Normative motives & & $\begin{array}{l}.183^{* *} \\
(.144)\end{array}$ \\
\hline Mimetic motives & & $\begin{array}{l}-.198 * * \\
(.141)\end{array}$ \\
\hline Internal efficiency motives & & $\begin{array}{l}.166^{*} \\
(.157)\end{array}$ \\
\hline SMEs commitment & & $\begin{array}{l}.301 * * \\
(.141)\end{array}$ \\
\hline $\mathbf{R}^{2}$ & .009 & .368 \\
\hline Adj. $\mathbf{R}^{2}$ & -.002 & .342 \\
\hline
\end{tabular}

Standard errors are in parentheses

$* \mathrm{p}<0.05 ; * * \mathrm{p}<0.01$ 
Table 4: Summary of the hypotheses and results

\begin{tabular}{|c|c|c|c|}
\hline Hypotheses & $\begin{array}{c}\text { Independent } \\
\text { Variable } \\
\end{array}$ & Results & Finding \\
\hline $\begin{array}{l}\text { H1: The later the time of adoption } \\
\text { of CMS the greater is the } \\
\text { probability that an SME } \\
\text { implements such standards owning } \\
\text { to coercive motives. }\end{array}$ & $\begin{array}{c}\text { Coercive } \\
\text { motives }\end{array}$ & $\begin{array}{c}\mathrm{b}=-.246 \\
\mathrm{t}=-3.472 \\
\mathrm{p}<.01\end{array}$ & Supported \\
\hline $\begin{array}{l}\mathrm{H} 2 \text { : The earlier the time of } \\
\text { adoption of CMS the greater is the } \\
\text { probability that an SME } \\
\text { implements such standards owning } \\
\text { to normative motives as perceived } \\
\text { by adopters. }\end{array}$ & $\begin{array}{l}\text { Normative } \\
\text { motives }\end{array}$ & $\begin{array}{c}\mathrm{b}=.183 \\
\mathrm{t}=2.690 \\
\mathrm{p}<.01\end{array}$ & Supported \\
\hline $\begin{array}{l}\text { H3: The later the time of adoption } \\
\text { of CMS the greater is the } \\
\text { probability that an SME } \\
\text { implements such standards owning } \\
\text { to mimetic motives as perceived by } \\
\text { adopters. }\end{array}$ & $\begin{array}{l}\text { Mimetic } \\
\text { motives }\end{array}$ & $\begin{array}{c}\mathrm{b}=-.198 \\
\mathrm{t}=-2.821 \\
\mathrm{p}<.01\end{array}$ & Supported \\
\hline $\begin{array}{l}\text { H4: The earlier the time of } \\
\text { adoption of CMS the greater is the } \\
\text { probability that an SME } \\
\text { implements such standards owning } \\
\text { to internal efficiency motives as } \\
\text { perceived by adopters. }\end{array}$ & $\begin{array}{l}\text { Internal } \\
\text { efficiency } \\
\text { motives }\end{array}$ & $\begin{array}{l}\mathrm{b}=.166 \\
\mathrm{t}=2.395 \\
\mathrm{p}<.05\end{array}$ & Supported \\
\hline $\begin{array}{l}\text { H5: The earlier the time of } \\
\text { adoption the more likely SMEs } \\
\text { will choose to commit fully to } \\
\text { CMS requirements. }\end{array}$ & $\begin{array}{c}\text { SMEs } \\
\text { commitment }\end{array}$ & $\begin{array}{l}\mathrm{b}=.301 \\
\mathrm{t}=4.514 \\
\mathrm{p} \quad<.001\end{array}$ & Supported \\
\hline
\end{tabular}

